\title{
Leader And Follower Factors In Customer And Employee Satisfaction: It Takes Two To Tango
}

Sooksan Kantabutra, (Email: sooksan.k@cmmu.net), Mahidol University, Thailand

\begin{abstract}
This study examined relationships between followers' shared visions, their use of their leader's vision and their own emotional commitment to the vision, and customer and employee satisfaction, simultaneously taking into account vision communication on the leader's part, in one hundred and eleven retail apparel stores. All were directly associated with customer and employee satisfaction. Among a few studies endorsing the critical role of followers in modern organizations, the study suggests important managerial implications for aspiring leaders.
\end{abstract}

\section{INTRODUCTION}

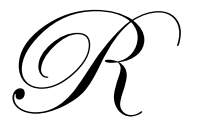

esearch into leadership has traditionally focused on either individual leaders or the broad strategic leadership sphere (Avery, 2004). The follower role in a visionary leadership process has been largely overlooked by researchers (Daft, 2005; House \& Aditya, 1997; Howell \& Shamir, 2005). The visionary leadership process here is defined as one through which a leader formulates a vision, communicate it to his/her followers who then share and become emotionally committed to the vision, and use the vision to guide their daily operations for the attainment of the vision.

Two follower variables are identified in the literature: followers' use of their leader's vision to guiding daily operations and followers' emotional commitment to the vision. Exploring the follower variables without taking into consideration how a vision is communicated to and shared by followers would oversimplify the situation. Therefore, both vision communication and shared vision are taken into account in this study.

Although the complex chain of relationships among follower emotional commitment to vision, follower use of vision to guide, vision communication, shared vision, and performance outcomes are little understood, thirteen hypotheses were developed and tested to explore the relationships in retail stores in Sydney, Australia. Customer and employee satisfaction were adopted as two performance outcomes. The literature review for each relevant variable is discussed below. Research methodology, findings and future research directions are also discussed.

\section{DEFINING VISION}

Although leadership with vision as a core component has been said to positively impact organizational performance (e.g. Bass, 1990; House \& Aditya, 1997; Isenberg, 1987; Maccoby, 1981), research into it is complicated by a lack of clear vision definitions (Kantabutra \& Avery, 2002). Avoiding the confusion, Baum, Locke, \& Kirkpatrick (1998) accepted the "vision" as defined by each leader, arguing that it is the leader's actual vision that guides his/her behavior. This approach was adopted in this study because each leader develops a vision in his/her own way (Nanus, 1992) with a different leadership style and vision content, and operating context also varies widely (Westley \& Mintzberg, 1989). Thus, it serves the exploratory purpose of this study to consider the effects of visionary tools that the leader actually employs, rather than adopting a possibly unrelated theoretical definition. 


\section{DEFINING A SHARED VISION}

A vision shared between leader and followers has been widely regarded as a key to outstanding performance (e.g. Bass, 1985; House \& Aditya, 1997; Howell \& Shamir, 2005; Senge, 1990). Without a shared vision, the leader will find it difficult to induce his/her followers to work toward desirable common goals. From a New Science perspective (Drath, 2001), that effective leadership requires an alignment between leader and followers underlines the importance of the aligning and sharing of visions held by organizational members.

The literature review identifies two essential components of a vision: Vision attributes and content. In a shared vision, attributes and content should be common, because both reflect common future directions between leader and followers of an organization.

\section{Vision Components}

In terms of vision attributes, scholars appear to disagree about the qualities necessary for a vision to create a positive impact on performance outcomes (see details in Kantabutra \& Avery, 2002). From the different qualities proposed for visions, commonalities have been identified for use in this study: brevity, clarity, future orientation, stability, challenge, abstractness and desirability or ability to inspire (Avery, 2004). In his effort to develop a vision theory, Kantabutra (2003) asserted that the seven vision attributes are required to interact with each other to impact overall organizational performance initially through organizational members.

There is no common agreement on effective vision content in the literature, and many leaders even have difficulty explaining how they arrived at their vision (Nanus, 1992). However, Westley and Mintzberg (1989) stated that the strategic content of a vision may focus on products, services, markets, organizations or even ideals. A successful vision appears to take into account industry, customers, and an organization's specific competitive environment in identifying a unique competitive position in the industry (Pearson, 1989), ideally differentiating the content across visionary organizations (Collins \& Porras, 1994).

In this study, customer and employee satisfaction imageries were adopted as vision content, because it was expected that the more store managers envisaged satisfying customers and employees, the higher the customer and employee satisfaction would be.

Therefore a shared vision was defined in this study as the similarity in the personal visions of a store manager and his/her employees, in terms of the seven vision attributes and content. This similarity was statistically assessed, the discussion of which will be in the following Method section.

\section{DEFINING VISION COMMUNICATION}

In developing a shared vision, leaders are preached to skilfully communicate their vision to their followers so that they will accept and share the vision, be emotionally committed to the vision, and use the vision to guide business activities within their roles and responsibilities. This is the reason vision-based leadership theories emphasize the importance of communicating a vision in bringing about superior performance outcomes (e.g. Bass, 1985; Bennis \& Nanus, 1985; Conger \& Kanungo, 1987; Cowley \& Domb, 1997; House, 1977; Kouzes \& Posner, 1987; Locke, Kirkpatrick, Wheeler, Schneider, Niles, Goldstein, Welsh, \& Chah, 1991; Nanus, 1992; Tichy \& Devanna, 1986).

Bennis and Nanus (1985) endorsed the importance of getting an organization to accept and support a vision by communicating the vision in a variety of ways, both written and orally. Moreover, the importance of a leader's inspiring followers through speeches and pep talks that get them to work toward a vision was also underlined (Bass, 1985; Tichy \& Devanna, 1986). Conger and Kanungo (1987) as well as Locke et al. (1991) proposed that leaders must use their personal communication skills, including speaking and listening skills, to articulate a vision to followers.

In addition, many organizational communication authors have suggested that technological developments are creating cheaper, more accessible, and more varied channels of communication (e.g. Pace \& Faules, 1994; 
Ruchsinskas, Svenning, \& Steinfield, 1990; Witherspoon, 1997). These communication channels include, for example, electronic mail, videoconferencing, voice messaging, fax, chat rooms, and electronic bulletin boards. These media are, therefore, also possible channels for leaders to communicate their vision directly to followers.

Therefore, vision communication in this study was defined as the degree to which a store manager communicated his/her vision to his/her employees through spoken, written and technology-mediated channels.

\section{DEFINING FOLLOWER FACTOR}

Although visionary leadership can occur at all levels of an enterprise, authors tend to focus on top leaders who capture the hearts and minds of their followers with their images of some desired future state (Avery, 2004). These exceptional leaders are expected to communicate a clear vision of the future because their power depends on acceptance, sharing and emotional commitment to the vision by followers. Followers' reactions to the vision, in terms of use, implementation, and emotional commitment are essentially central to translating the leaders' vision from words into actual behavior throughout the organization. From the few authors discussing follower roles in the visionary leadership process, the following variables emerged: the vision guides followers' work (Conger \& Kanungo, 1988; Lipton, 1996); and followers are emotionally committed to the vision (Collins \& Porras, 1994; House \& Shamir, 1993; Lipton, 1996). Each is discussed below.

\section{Use Of Vision To Guide}

Followers of a visionary leader are expected to be proactive, have a responsibility to participate in the group, work towards the vision and make their voices heard in influencing what is accomplished (Avery, 2004). In doing so, followers' use of their leader's vision in guiding their work is important to bring about desirable performance outcomes (e.g. Conger \& Kanungo, 1988; Lipton, 1996; Senge, 1990; Sergiovanni, 1990; Shamir, House, \& Arthur, 1993). One function of a vision is to facilitate decision-making, initiative, and discretion by followers at all levels (Yukl, 1998). Knowing the organization's central purpose and objectives helps the followers to determine what behavior that is appropriate, important or trivial. A good vision must "grab people in the gut" and motivate them to work toward a common end (Collins \& Porras, 1991), and allow each organizational member to act independently but in the same direction. Therefore, whether and how followers use the vision to guide their work could impact individual and collective performance outcomes.

Vision guiding was defined in this study as the extent to which an employee uses his/her store manger's vision to guide his/her daily operations.

\section{Emotional Commitment To Vision}

A powerful vision helps followers believe that they can be effective, and that there is a better future they can move to through their own affective commitment and actions (Daft, 2005). Vision is indeed an emotional appeal to fundamental human needs and desires - to feel important and useful, to believe ones can make a real difference in the world (Bennis \& Nanus, 1985). Realizing this, visionary leaders obtain their considerable power from, among others, their appealing vision and followers' emotional attachments to the vision (Shamir et al., 1993).

Followers' emotional commitment to their leader's vision is considered necessary for a vision to take effect, because when followers are committed, they tend to be willing to work toward the vision (Collins \& Porras, 1994; Lipton, 1996; Shamir et al., 1993). Vision really inspires people by transcending the bottom line (Nanus, 1992). When followers are emotionally committed, they are most likely to be willing, even eager, to commit voluntarily and completely to something that enables their own organization to grow and progress (Nanus, 1992). Therefore, whether and how followers are emotionally committed to their leader's vision could influence individual and collective performance outcomes.

Emotional commitment was defined in this study as the extent to which an employee believes in his/her store manager's vision and does whatever it takes to achieve the vision. Since followers' use of their leader's vision to 
guide their operations and their emotional commitment to the vision can theoretically influence performance outcomes, both variables form the Follower factor in this study.

\section{CUSTOMER AND EMPLOYEE SATISFACTION}

Customer and employee satisfaction were adopted in this study as performance outcomes because they are more responsive to leaders' behavior within the short time frame of the study than financial measures, and were not difficult to obtain from small businesses. Moreover, both customer satisfaction (e.g. Bird, 1995; Gates, 2000; Sitzia \& Wood, 1997) and employee satisfaction (e.g. Anderson, 1984; Barbin \& Boles, 1996; Tompkins, 1992) have been cited as leading performance indicators in various business organizations. Employee satisfaction is also considered closely related to customer satisfaction (e.g. Atchison, 1999; Faye \& Diane, 1995). This is attributed to customer satisfaction or dissatisfaction developing when a customer comes in contact with employees (Evans \& Lindsay, 1996). Customer satisfaction is additionally said to be a leading indicator of other critical measures of business performance such as customer loyalty, profit, market share, and growth (e.g. Anderson, Fornell, \& Lehman, 1994; Bolton \& Drew, 1991; Buzzell \& Gale, 1987).

Employee satisfaction was measured by the six components of job satisfaction developed by Slavitt, Stamps, Piedmont, \& Hasse (1986). Customer satisfaction was measured by 14 items of customer satisfaction developed by Hackl, Scharitzer, \& Zuba (2000). Since customer and employee satisfaction are significantly correlated, vision communication, shared vision and the Follower factor were tested against each performance outcome separately to prevent autocorrelation effects.

\section{HYPOTHESES}

Relationships among shared vision between leader and followers, vision communication, follower use of vision to guide, follower emotional commitment to vision, and employee and customer satisfaction are complex and not yet well understood. Figure 1 depicts a model tested in this study that proposes links between shared vision, vision communication, the Follower factor, and employee satisfaction derived from the literature. According to the literature, I expected that vision communication, shared vision, and the Follower factor created direct and positive impact on employee satisfaction.

Figure 1: Vision Communication, Shared Vision, and Follower Factor - Employee Satisfaction Path Model.

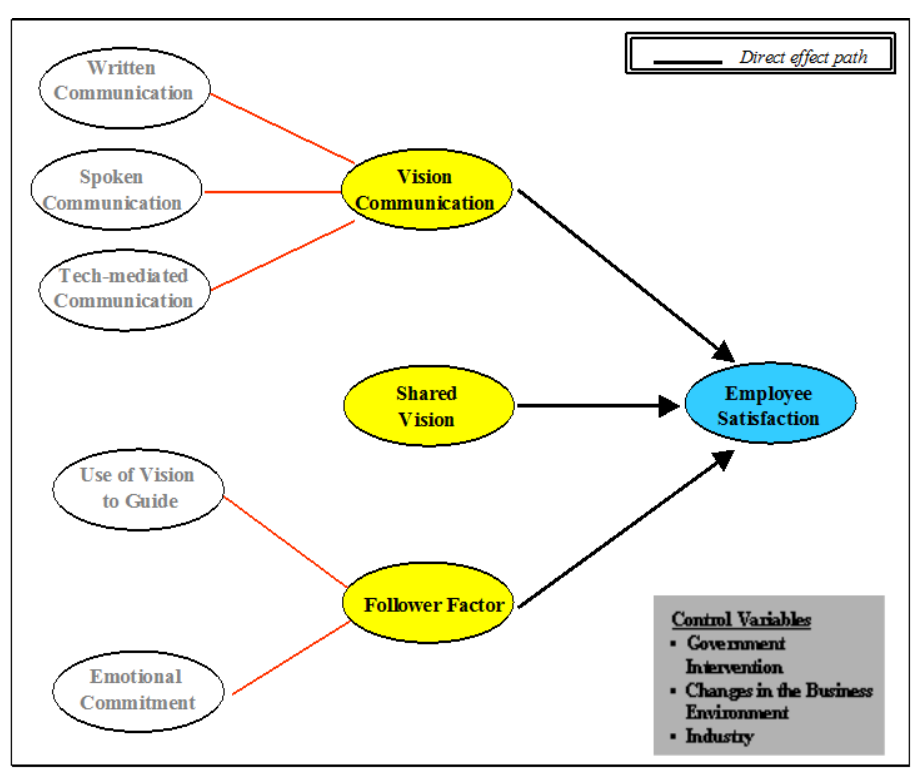


Similarly, Figure 2 depicts a model proposing links between shared vision, vision communication, the Follower factor, and customer satisfaction derived from the literature, using variables relating to the retail sector. Since vision is communicated to employees, and it is the employees who are emotionally committed to the vision and use the vision to guide, it is very unlikely that these variables will create any direct effects on customers. Therefore, I expected that these variables created indirect effects on customer satisfaction instead.

Figure 2: Vision Communication, Shared Vision, and Follower Factor - Customer Satisfaction Path Model.

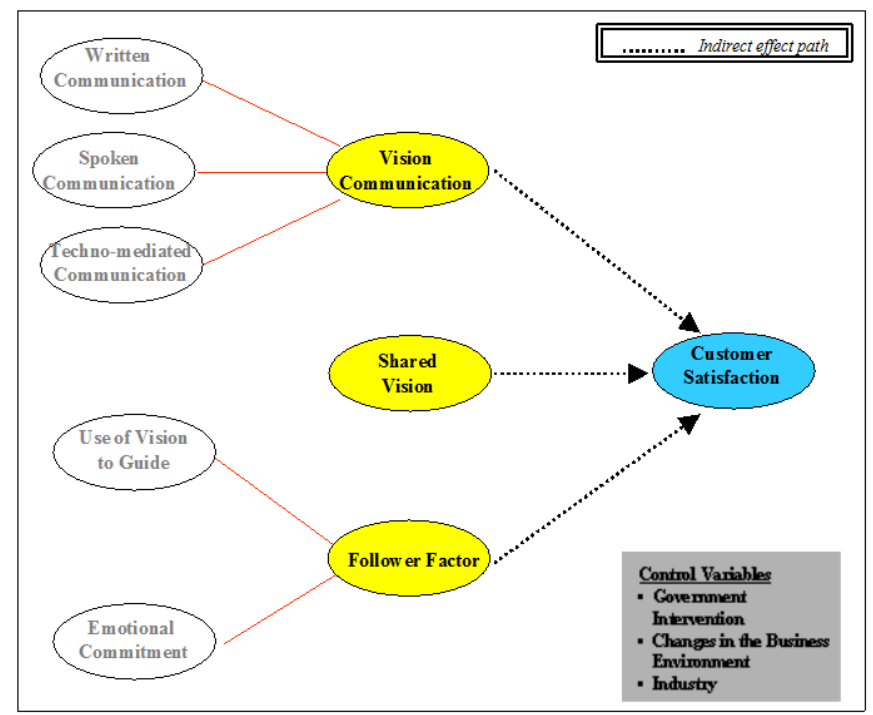

Based on the two models, the following hypotheses were formed. All hypotheses are directional because the literature emphasizes that shared vision, vision communication, and followers espousing a vision create a positive impact on performance outcomes.

$\mathbf{H}_{1}$ : Customer satisfaction is higher in stores with a manager having a vision.

$\mathbf{H}_{2}$ : Employee satisfaction is higher in stores with a manager having a vision.

$\mathbf{H}_{3}$ : There is a positive correlation between vision communication and customer satisfaction.

$\mathbf{H}_{4}$ : There is a positive correlation between vision communication and employee satisfaction.

$\mathbf{H}_{5}$ : There is a positive correlation between shared vision and customer satisfaction.

$\mathbf{H}_{6}$ : There is a positive correlation between shared vision and employee satisfaction.

$\mathbf{H}_{7}$ : There is a positive correlation between the Follower factor and customer satisfaction.

$\mathbf{H}_{\mathbf{8}}$ : There is a positive correlation between the Follower factor and employee satisfaction.

$\mathbf{H}_{\mathbf{9}}$ : Vision communication, shared vision, and the Follower factor are directly associated with enhanced employee satisfaction.

$\mathbf{H}_{10}$ : Vision communication, shared vision, and the Follower factor are indirectly associated with enhanced customer satisfaction.

Since Hallinger and Heck (1998) stress the need for leadership research to investigate causal relationships that may be multi-directional and non-linear, I also investigated possible reciprocal effects among these variables in the pursue of understanding the complex chain of relationships among them.

First, one may argue that vision communication, shared vision and employee satisfaction can also influence employees' use of their store manager's vision to guide daily operations and their emotional commitment to the store manager's vision. For example, where a store manager communicates his vision, employee satisfaction is likely to 
increase. This affects emotional commitment to the manager's vision, which in turn is likely to drive actual use of the vision in one's work. Therefore, the following hypothesis was formed to test this alternative relationship.

$\mathbf{H}_{11}$ : Vision communication, shared vision and employee satisfaction are directly associated with enhanced Follower factor.

Second, one may argue that vision communication, the Follower factor and employee satisfaction can influence the extent to which employees share their store managers' vision. In other words, when a store manager communicates his/her vision and his/her satisfied employees are committed to the vision and use the vision to guide their work, a vision will be more shared. Accordingly, the following hypothesis was formed to test this relationship.

$\mathbf{H}_{12}$ : Vision communication, employee satisfaction, and the Follower factor are directly associated with more shared vision.

The last reciprocal relationship proposed in this study is one between the Follower factor, shared vision, and employee satisfaction, and vision communication. It was expected that when emotionally committed, satisfied employees used their store managers' vision to guide their work, the store managers would feel comfortable to communicate their visions more frequently. Therefore, the following hypothesis was formed.

$\mathbf{H}_{13}$ : Employee satisfaction, shared vision and the Follower factor are directly associated with more frequent vision communication.

\section{METHOD}

External factors were controlled in this study by conducting it in a specific retail industry, at a specific period in time. The sample was drawn from apparel stores in Sydney, Australia, that sell brand-new, finished clothing products for individual use. Both independent stores and those belonging to a parent company were sampled.

Nineteen major shopping centers were selected and all qualifying stores approached. Of these, 111 stores (70\%) agreed to participate, with 48 stores (30\%) declining. From the participating stores, store managers, and up to three employees and three customers were interviewed.

Store managers refer to those fulltime store employees who manage their own stores and are stationed there daily. One hundred and eleven store managers participated in the survey. The 148 employees interviewed include fulltime, parttime and casual employees working under the store managers, and the 214 customers surveyed were individuals who were observed buying a product or service during a researcher's visit. The average number of employees sampled per store was 1.3, ranging across the stores from one to three employees per store. The average number of customers sampled per store was 1.3, ranging from one to three employees per store. The average number of customer sampled per store was 1.9, ranging across the stores from one to three employees per store.

\section{Data Collection And Analysis}

Separate questionnaires were used for store managers, employees and customers. A nine-point ordinal scale underlay all questionnaire items measuring all measurement domains, but the shared vision which is discussed next. Three trained researchers interviewed store managers and their employees and customers. The response rate of the store manager respondents was $70 \%$. Response rates for employees and customers were $44 \%$ and $64 \%$ respectively.

The store manager questionnaire collected demographic and vision data, including asking the store managers whether they had a vision for their stores. If they did, they were asked to write down their vision statements. The employee questionnaire asked about vision communication from their store manager, their use of vision to guide and emotional commitment to the store manager's vision. They were also asked if they had a personal vision for their store. If they did, they were asked to write down their personal vision statements. Employees also responded to the six 
components of job satisfaction. The customer questionnaire collected data on the 14 items measuring customer satisfaction with services at the store.

Convergent and discriminant validity for vision communication and Follower factor domains were sufficiently represented $(\mathrm{p}<0.05)$, although some subvariables designed to measure one construct correlated with other subvariables intended to measure other constructs. This is possible because convergent and discriminant validity are never all-or-nothing constructs, making it impossible to "prove" the construct validity of a measured variable (Stangor, 1998).

All scales associated with the Follower factor, vision communication and customer \& employee satisfaction were unidimensional (coefficient values $>0.3$, see Taris \& Bok, 1998). All scales indicated reliability values exceeding, or very close to, 0.8 (Fornell \& Larcker, 1981), with an exception of the Follower factor which had a relatively weak Alpha value of 0.52 . By convention, one-tailed tests were adopted at the $5 \%$ level of significance for testing all hypotheses.

\section{Deriving Shared Vision Value}

Kantabutra's (2003) approach was adopted to determine the shared vision value. Vision statements from both store manager and employee respondents were rated on a five-point ordinal scale by three trained independent raters, using the definitions that were derived from Baum (1996, p.193). A score of five indicates the highest degree of the presence of a vision attribute or content imagery in the vision statement, while a score of zero indicates the absence of a vision attribute or content imagery.

The shared vision value is a score that indicates how similar the personal visions reported by employees were to the vision reported by their store manager, in terms of the seven vision attributes and two vision content components. The vision rating process described above yielded seven attributes and two imagery scores for each vision from each store manager and employee.

Of the 81 stores with a vision, 43 (53\%) had one employee who reported having his/her own vision. These personal vision scores were used in the shared vision calculation. In eight $(9.9 \%)$ stores reporting a vision, two or more employees provided a personal vision. In stores where multiple visions were found, employee vision scores were averaged to find a representative vision score for the shared vision calculation. Although employees who claimed to have no personal vision did not report having goals in conflict with their store manager's vision, this does not mean that they shared their store manager's vision either. Therefore, data from employees without a vision were excluded from the shared vision calculation.

After each of the nine averaged employee vision scores was calculated, the nine store manager vision scores and the nine employee vision scores were correlated for each store. Each resulting correlation value in turn formed a shared vision score for its respective store. Interrater reliability was 0.98 , indicating sufficient reliability (Fornell \& Larcker, 1981). All vision scales indicated reliability values exceeding 0.8, a guideline for acceptable reliability (Fornell \& Larcker, 1981).

\section{RESULTS ( $r$ and $\beta$ values available upon request)}

Store managers had been with the stores for 3.39 years on average. Employees consisted of full-time (30\% of respondents), part-time (23\%), and casual (47\%) respectively, and had worked in their stores for an average of 2.64 years. Stores averaged 6.29 employees in total, including 2.34 full-time, 2.47 part-time, and 4.35 causal employees. Among the 111 stores, 81 (73\%) store managers reported having a vision for their store. Examples of store manager's visions are shown in Table 2. Averaged total scores and pooled standard deviations for the major dependent and independent variables are presented in Table 1. 
Table 1: Means and Standard Deviations for Major Variables.

\section{Descriptive Statistics}

\begin{tabular}{|l|r|r|r|r|}
\hline & \multicolumn{1}{|c|}{ N } & \multicolumn{1}{c|}{ Range } & \multicolumn{1}{c|}{ Mean } & Std. Deviation \\
\hline STO_VCOM & 83 & 24.00 & 14.3855 & 5.42315 \\
Shared Vision & 39 & 1.42 & .4210 & .35765 \\
STO_FF & 84 & 34.00 & 29.8810 & 7.07176 \\
TSTF_SAT & 111 & 70.00 & 75.6757 & 15.02795 \\
TCUS_SAT & 111 & 68.00 & 95.0360 & 15.35100 \\
Valid N (listwise) & 38 & & & \\
\hline
\end{tabular}

Table 2: Examples of Store Manager Vision Statements.

\begin{tabular}{|c|}
\hline Store Manager Vision Statements \\
\hline To be known as the most interesting store in Sydney. \\
\hline $\begin{array}{l}\text { To have a fun \& productive work environment for both staff and customers with } \\
\text { complete customer satisfaction. }\end{array}$ \\
\hline $\begin{array}{l}\text { To get all staff to the same level of competency as to achieve maximum sales. Also for } \\
\text { every customer to enjoy their shopping experience to result in repeated customers. }\end{array}$ \\
\hline Become one of the well-known fashion store in Sydney. \\
\hline To maximize my clientele and provide the best service and prices. \\
\hline $\begin{array}{l}\text { To create an open, warm, and friendly environment where people are not pressured, but } \\
\text { can enjoy themselves whilst maintaining a professional service approach. }\end{array}$ \\
\hline
\end{tabular}

All following hypotheses were tested at $\mathrm{p}<0.05$. In testing Hypotheses 1 and 2, chi-squared values indicated significant associations between overall customer and employee satisfaction, and stores with a manager having a vision $\left(\chi^{2}=34.72\right.$ and 15.69 respectively). Hypothesis 3 was tested using correlation, yielding no signification relationship. Similarly, Hypothesis 4 was tested, resulting in a significant, positive relationship between vision communication and employee satisfaction. In testing Hypotheses 5 and 6, significant, positive relationships were found between shared vision and both customer and employee satisfaction.

In testing Hypothesis 7, the correlation analysis performed between the Follower factor and customer satisfaction, revealed no significant relationship. In testing Hypothesis 8, a correlation analysis between the Follower factor and employee satisfaction suggested a positive relationship.

In testing Hypothesis 9, a regression analysis was performed, revealing three direct, significant relationships between vision communication, shared vision, and Follower factor, and employee satisfaction. However, the hypothesis was rejected because a negative relationship was found between vision communication and employee satisfaction. Similarly in testing Hypothesis 10, a regression analysis was performed, revealing three direct significant relationships between vision communication, shared vision, and Follower factor, and customer satisfaction. Since the relationship between vision communication and customer satisfaction was negative, the hypothesis was rejected.

In testing Hypothesis 11, a regression analysis was performed, revealing two significant, direct relationships between vision communication and employee satisfaction, and enhanced Follower factor. However, the hypothesis was rejected because shared vision was not significantly associated with the Follower factor. In testing Hypothesis 12 , 
a regression analysis was performed, revealing a significant, direct relationship between employee satisfaction and enhanced shared vision. However, the hypothesis was rejected because vision communication and the Follower factor were not significantly associated with shared vision.

In testing Hypothesis 13, a regression analysis was performed between the Follower Factor, employee satisfaction, and shared vision, and vision communication. It reveals two significant relationships between the Follower factor and employee satisfaction, and vision communication. Therefore, the hypothesis was rejected because there was no significant relationship between shared vision and vision communication, and the relationship between employee satisfaction and vision communication was negative.

In conclusion, Hypotheses $1-2$ were accepted. Hypothesis 3 was not accepted, while Hypothesis 4 was. Hypotheses $5-6$ were both accepted. Hypothesis 7 was not accepted, while Hypothesis 8 was. Hypotheses 9, 10, 11, 12 and 13 were not accepted, although they were partially supported.

\section{DISCUSSION}

To demonstrate the complex relationships of the observed variables, the Discussion section is divided into two subsections: Discrete and Simultaneous Effects.

\section{Discrete Effects}

As anticipated, that stores with a manager having a vision are associated with enhanced customer and employee satisfaction $\left(\mathbf{H}_{1}, \mathbf{H}_{2}\right)$ supports prior claims in the literature that espousing a vision creates positive effects on performance outcomes (e.g. Bass, 1990; House \& Aditya, 1997; Isenberg, 1987; Maccoby, 1981). Looking more closely at the results, store managers who communicated their vision to their employees are correlated with enhanced employee satisfaction $\left(\mathbf{H}_{\mathbf{4}}\right)$, lending broad support to the vision-based leadership theories that vision communication is critical to employee satisfaction and other performance outcomes (e.g. Hewitt Associates, 2001; Kotter, 1995; Lipton, 1996). There is no significant correlation between vision communication and customer satisfaction $\left(\mathbf{H}_{3}\right)$ here however. This suggests that store managers communicating their vision to employees per se do not have any effect on customer satisfaction.

In terms of shared vision, it is interesting that the more store managers and their employees sharing a vision, the higher both customer and employee satisfaction $\left(\mathbf{H}_{5}, \mathbf{H}_{6}\right)$. A shared vision between a leader and his/her followers is indeed critical to overall organizational performance since both customer and employee satisfaction are usually highly correlated, and customer satisfaction frequently bring about superior overall performance (Anderson, Fornell, \& Lehman, 1994; Bolton \& Drew, 1991; Buzzell \& Gale, 1987). This finding also endorses many views about the importance of the congruence between leader and follower visions (e.g. Bass, 1985; Drath, 2001; Hallinger \& Heck, 2002; Senge, 1990).

In testing the relationships between the Follower factor, and customer and employee satisfaction, the results indicate that the more employees used their store manager's visions to guide their daily operations and the more they were emotionally committed to their store manager's visions, the higher their own satisfaction $\left(\mathbf{H}_{\mathbf{8}}\right)$. One explanation for this may be because the Australian retail industry was going through significant change and disruption (Australian Retailers Association, 2001), employees therefore might be looking for a direction. Given a desired vision or strategic direction, employees might be clear and emotionally committed to the long-term direction of their organization. Therefore they acted within their roles and responsibilities to turn the vision into reality. In doing so, they were not confused by the fast changing environment. This might enhance their satisfaction. This finding also accentuates the role of vision as a navigator in times of change because vision is said to possess potent orienting capacities (Davis \& Meyer, 1998). The finding also lends broad support to the views that: (a) followers' use of their leader's vision as a guide in their work is important to organizational performance (e.g. Conger \& Kanungo, 1988; Lipton, 1996; Senge, 1990); (b) a vision can facilitate decision-making, initiative, and discretion by followers (Yukl, 1998). 
Given that the Follower factor was not significantly correlated with customer satisfaction $\left(\mathbf{H}_{7}\right)$, it can be interpreted that both employees' use of vision to guide daily operation and their emotional commitment to their store managers' vision alone do not have any effect on customer satisfaction. This relationship will be discussed further in the following subsection.

\section{Simultaneous Effects}

In further testing for simultaneous effects from vision communication, shared vision and the Follower factor on employee satisfaction $\left(\mathbf{H}_{\mathbf{9}}\right)$, all three variables rendered significant, direct effects upon employee satisfaction although only vision communication rendered a negative effect. To explain the phenomenon that both shared vision and the Follower factor created positive effects on employee satisfaction, I suspect that work is an activity during which cognition about a goal to be achieved and affective commitment of an employee are strongly related. Therefore, the congruence between the store manager's vision communicated to his/her employees and employees' personal visions about this goal may facilitate that employees engage their emotion to carry the goal outside. Moreover, this shared vision finding also lends support to an assertion that the congruence between vision of a manager and those of his/her employees is a condition necessary for the satisfaction of employees so that their work remains related to the vision (e.g. McClelland 1985a, 1985b quoted by House, Spangler \& Woycke, 1991).

On contrary to the views expressed by many scholars and prior empirical evidence in the literature, vision communication was found to create a negative effect upon employee satisfaction, where shared vision and the Follower factor were simultaneously taken into account. It must be pointed out here that vision communication was positively correlated with employee satisfaction in the prior correlation analysis $\left(\mathbf{H}_{4}\right)$. Clearly, the effects from shared vision and/or the Follower factor influenced the direction of vision communication effect in the regression analysis. One explanation is that when employees already share their store managers' vision and are already emotionally committed to and using the vision, store managers who still communicate their vision to them might decrease employee satisfaction. Employees might be upset by too much vision communication. Therefore, future research needs to identify the optimal level of vision communication in such a context.

The most notable discovery of this present study is when vision communication, shared vision and the Follower factor were significantly directly associated with customer satisfaction $\left(\mathbf{H}_{\mathbf{1 0}}\right)$, although vision communication and the Follower factor were not significantly correlated with customer satisfaction in the prior correlation analyses $\left(\mathbf{H}_{3}, \mathbf{H}_{7}\right)$. Future research may want to explore whether it is the shared vision, as it appears to be at first glance, that enables the significant direct effects from vision communication and the Follower factor on customer satisfaction.

Looking at alternative causal directions, it was found that vision communication and employee satisfaction were drivers of the Follower factor $\left(\mathbf{H}_{\mathbf{1 1}}\right)$. In other words, the more store managers communicate their vision, the more employees are satisfied, the more the employees would be emotionally committed to their store managers' vision, and use the vision to guide their daily operations. On the contrary to what common senses might suggest, a shared vision had no role in bringing about employee emotional commitment and the use of vision as a guide in this study.

In testing for reciprocal effects from vision communication, employee satisfaction, and the Follower factor on shared vision $\left(\mathbf{H}_{\mathbf{1 2}}\right)$, employee satisfaction was the only significant variable in the regression analysis. It can be interpreted that the more employees are satisfied with their work and relationship with their manager, the more a vision can be shared. One explanation for this is that employees who are satisfied with their jobs and/or their relationship with their manager, more easily accept and share their manager's vision. This is akin to Howell and Shamir's (2005) concept of a personalised relationship with a leader. Some employees become emotionally attracted to the leader as person, and then become influenced by the leader's vision. Under a socialized view of attachment, employees are attracted to workplaces where they share the vision and values of the leader (Howell \& Shamir, 2005).

The regression analysis also reveals that the Follower factor and employee satisfaction were drivers to vision communication $\left(\mathbf{H}_{\mathbf{1 3}}\right)$, although employee satisfaction is not an additive factor to vision communication. How can decreased employee satisfaction, higher emotional commitment to vision and more frequent use of vision to guide 
explain variation in vision communication? One explanation is that when employee satisfaction is relatively low, the emotionally committed employees who use the vision to guide may appear to their store manager to need a reconfirmation of direction. Therefore, the store manager might increase the frequency of vision communication on his part, which spirally and negatively affects employee satisfaction. Clearly, this proposition needs further testing.

In conclusion, vision communication, shared vision, and the Follower factor had reciprocal relationships with employee satisfaction. Taking into account shared vision and the Follower factor, the reciprocal relationship between vision communication and employee satisfaction was negative, while the reciprocal relationships between shared vision and the Follower factor, and employee satisfaction were positive. Vision communication, shared vision, and the Follower factor had direct relationships with customer satisfaction, although only the one between vision communication and customer satisfaction was a negative one.

\section{FUTURE RESEARCH DIRECTIONS}

Like many other studies, this present study is not without any limitation. First, the Follower factor reliability was relatively low. Future research may want to include other items to the measurement scale to enhance the reliability (see Kelly, 1992). It must be noted that the low reliability could also be a methodological artifact of the relatively low employee response rate. Therefore, future research needs to be aware of this limitation. In terms of the shared vision value, future research may opt to ask employee respondents to indicate the extent to which they share their leader's vision. This approach may offer a more reliable and meaningful value of shared vision.

In terms of vision communication and the Follower factor, this study only indicates their importance to both employee and customer satisfaction. However, the study does not explain how a vision is communicated, how employees become emotionally committed to the vision and how they use the vision to guide their work. In particular, how follower reactions to the vision contribute to other performance outcomes (e.g. profits) is still little understood. Another opportunity for future research is pointed out here.

Future researchers may take into account other vision content in examining employee use of vision to guide and employee emotional commitment to vision. Some qualities in a vision might be easier to gain emotional commitment from employees and be used by them than others.

\section{CONCLUSION}

Employees' personal visions shared with their store manager's vision, their emotional commitment to their store manager's vision, and their use of their store manager's vision to guide daily operations were directly associated with both customer and employee satisfaction, simultaneously taking into account the effect from vision communication on the store manager's part. Although vision communication was directly associated with customer and employee satisfaction, it was for negative ways. Reciprocal relationships among vision communication, shared vision, employee emotional commitment and use of vision to guide, and employee satisfaction were also found.

\section{REFERENCES}

1. Anderson, C. H. 1984. Job Design: Employee Satisfaction and Performance in Retail Stores. Journal of Small Business Management, 22(4): 9-16.

2. Anderson, E. W., Fornell, C., \& Lehman, D. R. 1994. Customer Satisfaction, Market Share, and Profitability: Findings from Sweden. Journal of Marketing, 58(July): 53-66.

3. Atchison, T. 1999. The Myths of Employee Satisfaction. Healthcare Executive, March/April: 19-23.

4. Australian Retailers Association. 2001. Retail Industry Profile 2001. Australian Retailers Association, Sydney, New South Wales.

5. $\quad$ Avery, G. C. 2004. Understanding Leadership. Thousand Oaks: Sage.

6. Barbin, B. J., \& Boles, J. S. 1996. The Effects of Perceived Co-worker Involvement and Supervisor Support on Service Provider Role Stress, Performance and Job Satisfaction. Journal of Retailing, 72(1): 57-75.

7. Bass, B. M. 1985. Leadership and Performance Beyond Expectations. New York: Free Press. 
8. Bass, B. M. 1990. Bass and Stogdill's Handbook of Leadership: Theory, Research, and Managerial Applications $\left(3^{\text {rd }}\right.$ ed.) New York: Free Press.

9. Baum, J. R. 1996. The Relations of Traits, Competencies, Vision, Motivation, and Strategy to Venture Growth. Doctoral dissertation, University of Maryland, UMI, Ann Arbor, Michigan, 9526175.

10. Baum, J. R., Locke, E. A., \& Kirkpatrick, S. A. 1998. A Longitudinal Study of the Relation of Vision and Vision Communication to Venture Growth in Entrepreneurial Firms. Journal of Applied Psychology, 83: 4354.

11. Bennis, W., \& Nanus, B. 1985. Leaders: The Strategy for Taking Charge. New York: Harper \& Row.

12. Bird, A. 1995. Performance Measurement for the Financial Services Industry. Community Banker, 1(5): 7 10.

13. Bolton, R. N., \& Drew, J. H. 1991. A Multistage Model of Customers' Assessments of Service Quality and Value. Journal of Consumer Research, 17(March): 375-384.

14. Buzzell, R. D., \& Gale, B. T. 1987. The PIMS Principles: Linking Strategy to Performance. New York: Free Press.

15. Collins, J. C., \& Porras, J. I. 1991. Organizational Vision and Visionary Organizations. California Management Review, (Fall): 30-52.

16. Collins, J. C., \& Porras, J. I. 1994. Built to Last: Successful Habits of Visionary Companies. Century: London.

17. Conger, J. A., \& Kanungo, R. N. 1987. Toward a Behavioral Theory of Charismatic Leadership in Organizational Settings. Academy of Management Review, 12: 637-647.

18. Conger, J. A., \& Kanungo, R. N. 1988. Charismatic Leadership: The Elusive Factor in Organizational Effectiveness. San Francisco, CA: Jossey-Bass.

19. Cowley, M. \& Domb, E. 1997. Beyond Strategic Vision. Boston, MA: Butterworth-Heinemann.

20. Daft, R. L. 2005. The Leadership Experience. Mason, OH: Thomson South Western.

21. Davis, S. \& Meyer, C. 1998. Blur: The Speed of Change in the Connected Economy. San Francisco: Addison-Wesley.

22. Drath, W. H. 2001. The Deep Blue Sea: Rethinking the Source of Leadership. San Francisco, CA: JosseyBass.

23. Evans, J. R., \& Lindsay, W. M. 1996. The Management and Control of Quality. MN: West.

24. Faye, M., \& Dianne, R. L. 1995. Transformational Leadership and Job Satisfaction. Nursing Management, 26(9): 64JJ-64NN.

25. Fornell, C., \& Larcker, D. 1981. Evaluating Structural Equation Models with Unobservable Variables and Measurement Error. Journal of Marketing Research, 18(February): 39-50.

26. Gates, S. 2000. Strategic Performance Measurement Systems: Translating Strategy Into Results. The Bank of America Journal of Applied Corporate Finance, 13(3): 44-59.

27. Hackl, P., Scharitzer, D., \& Zuba, R. 2000. Customer Satisfaction in the Austrian Food Retail Market. Total Quality Management, 11(7): S999-S1006.

28. Hallinger, P. \& Heck, R. 2002. What Do You Call People with Visions? The Role of Vision, Mission and Goals in School Leadership and Improvement. In K. Leithwood, P. Hallinger and Colleagues (Eds.), The Handbook of Educational Leadership and Administration (Second Edition). Dordrecht: Kluwer.

29. Hallinger, P., \& Heck, R. H. 1998. Exploring the Principal's Contribution to School Effectiveness: 19801995. School Effectiveness and School Improvement, 9 (2): 157-191.

30. Hewitt Associates. 2001. Best Employers to Work For in Australia. Hewitt Associates, Sydney, New South Wales.

31. House, R. J. 1977. A 1976 Theory of Charismatic Leadership. In Hunt, J. G. \& Larson, L. L. (Eds.). Leadership: The Cutting Edge (189-207). Carbondale: Southern Illinois University Press.

32. House, R. J. \& Shamir, B. 1993. Toward the Integration of Transformational, Charismatic and Visionary Theories of Leadership. In Chemers, M. \& Ayman, R. (Eds.). Leadership Theory and Research: Perspectives and Directions (81-107). San Diego, CA: Academic Press.

33. House, R. J., Spangler, W. D., \& Woycke, J. 1991. Personality and Charisma in the US Presidency: A Psychological Theory of Leader Effectiveness, Administrative Science Quarterly, 36: 364-396.

34. House, R.J. \& Aditya, R.N. 1997. The Social Scientific Study of Leadership: Quo Vadis? Journal of Management, 23(3): 409-473. 
35. Howell, J.M. \& Shamir, B. 2005. The Role of Followers in the Charismatic Leadership Process: Relationships and their Consequences, Academy of Management Review, 30(1): 96-112.

36. Isenberg, D. J. 1987. The Tactics of Strategic Opportunism. Harvard Business Review, March-April: $92-97$.

37. Kantabutra, S. 2003. An Empirical Examination of Relationships between Vision Components, and Customer and Staff Satisfaction in Retail Apparel Stores in Sydney, Australia. Unpublished PhD thesis, Macquarie Graduate School of Management, Sydney, Australia.

38. Kantabutra, S. \& Avery, G.C. 2002. Proposed Model for Investigating Relationships Between Vision Components and Business Unit Performance. Journal of the Australian and New Zealand Academy of Management, 8(2): 22-39.

39. Kelly, R. E. 1992. The Power of Followership: How to Create Leaders People Want to Follower, and Followers Who Lead Themselves. New York: Doubleday.

40. Kotter, J. P. 1995. Why Transformation Efforts Fail? Harvard Business Review, March-April: 59-67.

41. Kouzes, J. M. \& Posner, B. Z. 1987. The Leadership Challenge: How to Get Extraordinary Things Done in Organizations ( $1^{\text {st }}$ ed.). San Francisco: Jossey-Bass.

42. Lipton, M. 1996. Demystifying the Development of An Organizational Vision. Sloan Management Review, 37(4): 83-91.

43. Locke, E. A., Kirkpatrick, S., Wheeler, J. K., Schneider, J., Niles, K., Goldstein, H., Welsh, K., \& Chah, D. O. 1991. The Essence of Leadership. New York: Lexington Books.

44. Maccoby, M. 1981. The Leader. New York: Simon and Schuster.

45. Nanus, B. 1992. Visionary Leadership: Creating a Compelling Sense of Direction for Your Organization. San Francisco, CA: Jossey-Bass.

46. Pace, R. W. \& Faules, D. F. 1989. Organizational Communication (2 ${ }^{\text {nd }}$ ed.). New Jersey: Prentice Hall.

47. Pearson, A. E. 1989. Six Basics for General Managers. Harvard Business Review, 67(4): 94-101.

48. Ruchinskas, J., Svenning, L., \& Steinfield, C. W. 1990. Video Comes to Organizational Communications: The Case of ARCO Vision". In Sypher, B. D. (Ed.). Case Studies in Organizational Communication (269281). New York: The Guilford Press.

49. Senge, P. M. 1990. The Fifth Discipline: The Art and Practice of the Learning Organization. New York: Currency Doubleday.

50. Sergiovanni, T. J. 1990. Adding Value to Leadership Gets Extraordinary Results. Educational Leadership, 47(8): 23-27.

51. Shamir, B., House, R. J., \& Arthur, M. B. 1993. The Motivational Effect of Charismatic Leadership: A Selfconcept based Theory. Organization Science, 4: 577-594.

52. Sitzia, J., \& Wood, N. 1997. Patient Satisfaction: A Review of Issues and Concepts. Social Science Medical, 45(12): 1829-43.

53. Slavitt, D., Stamps, P., Piedmont, E., \& Hasse, A. 1986. Index of Work Satisfaction. MI: University of Michigan Press.

54. Stangor, C. 1998. Research Methods for the Behavioral Sciences. New York: Houghton Mifflin.

55. Taris, W. T., \& Bok, I. A. 1998. On Gender Specificity of Person Characteristics in Personnel Advertisements: A Study Among Future Applicants. Journal of Psychology, 132(6): 593-610.

56. Tichy, N. M., \& Devanna, M. A. 1986. The Transformational Leader. New York: Wiley.

57. Tompkins, N. C. 1992. Employee Satisfaction Leads to Customer Service. HR Magazine, 37(11): 93-97.

58. Westley, F., \& Mintzberg, H. 1989. Visionary Leadership and Strategic Management. Strategic Management Journal, 10: 17-32.

59. Witherspoon, P. D. 1997. Communicating Leadership: An Organizational Perspective. Needham, Massachusetts: Allyn \& Bacon.

60. Yukl, G. A. 1998. Leadership in Organizations. New Jersey: Prentice Hall. 


\section{NOTES}

